\title{
Production of Nd-Fe Foundry Alloy by Electrolysis in Molten Salts
}

\author{
Yuriy Makaseev ${ }^{1}$, Alexander Buinovskiy ${ }^{1,2}$, Sergey Zhitkov $^{1}$, Evgeniy Kartashov $^{1}$, and Vladimir Sofronov ${ }^{1, *}$ \\ ${ }^{1}$ National Research Nuclear University “Moscow Engineering Physics Institute”, Moscow, Russian Federation \\ ${ }^{2}$ National Research Tomsk State University, Tomsk, Russian Federation
}

\begin{abstract}
Nd-Fe-B-based permanent magnets have the highest magnetic characteristics. To improve their quality, one generally applies the technique of solid-phase alloying by materials with high content of neodymium, dysprosium, terbium, i.e. rare-earth metal (REM)-Fe(Co) foundry alloys. The paper presents the results of the study of the manufacturing process of Nd-Fe foundry alloys, with composition being close to eutectic, by electrolysis of neodymium oxides and fluorides from chloride and fluoride melts. It is shown that in the oxide electrolysis a sufficiently high current efficiency (over $98 \%$ ) is obtained. This is a promising method of obtaining of rare earth-containing materials.
\end{abstract}

\section{Introduction}

In Russia there has been developed the fluoride method of production of Nd-Fe-B-based magnetic alloys and rare earth foundry alloys $(\mathrm{Nd}, \mathrm{Pr}, \mathrm{Dy}, \mathrm{Tb})$, with a transition metal being Fe or Co. The method is based on the out-of-furnace calcium-thermic coreduction of anhydrous metal fluorides. The advantages and disadvantages of this method are presented in the paper [1].

Nd-Fe-B alloys are used for the production of highenergy permanent magnets. Foundry alloys are used either for the production of magnetic alloys by refining or for solid-phase alloying of magnetic alloys during the stage of their comminution, when magnets are produced by means of the powder metallurgy method.

The fluoride technique allows obtaining foundry alloys in the form of ingots; during the reduction smelting the yield is about $95 \%$ when iron and neodymium contents in the foundry alloy are close to calculated ones for the formation of low-melting eutectic (76.5\% wt. $\mathrm{Nd}-23.5 \mathrm{Fe}$ with the melting temperature $\mathrm{T}_{\mathrm{m}} \approx 640-650^{\circ} \mathrm{C}$ ) [2]. However, the fluoride technique has some disadvantages:

- the yield of foundry alloy is not high enough during the reduction smelting;

- the formation of fluoride slags (about $1 \mathrm{~kg}$ per $1 \mathrm{~kg}$ of the ligature); they are generally composed of $\mathrm{CaF}_{2}$ and it is hard to process them;

- considerable material and labour costs, connected with the production of anhydrous metal fluorides, calcium metal, graphite crucible manufacturing for the reduction smelting and the complication of the continuous process organization during main production steps.

In this regard, the search for better and economically sound methods of production of magnetic alloys, including Nd-Fe foundry alloy, is an urgent task for the further development of high-energy magnet production.

Therefore, along with the improvement of the out-offurnace fluoride technology we develop the electroplating technique for producing REMs (rare-earth metals) and foundry alloys, such as fusible $\mathrm{Nd}-\mathrm{Fe}$ foundry alloy. Electroplating techniques of REM and foundry alloy production are based on the electrolysis of fluorides, oxides or the mixture of fluorides and chlorides of alkali and earth metals in molten salts. At the same time, a carbon anode and an iron cathode are generally used when the electrolysis of neodymium fluoride or neodymium oxide is taking place [3-7]. The process is conducted at $650-1100^{\circ} \mathrm{C}$.

In our opinion, the electroplating technique of foundry alloy production has some advantages over the fluoride technology:

- the electrolysis process is controllable, and it allows controlling the progress of the process with the help of inspection tools and automatic equipment;

- neodymium fluoride consumption decreases; and application of an iron cathode, while using neodymium oxide as consumable supplies, excludes neodymium fluoride consumption;

- there is a real possibility of creating an electrolyzer for continuous operation with dosed charge of consumable supplies (neodymium oxide and neodymium fluoride) and periodic discharge of the molten foundry alloy during electrolysis; that will dramatically reduce the amount of wastes in the form of spent electrolyte.

\section{Experimental part}

The research was conducted in the experimental electrolyzer, which principle circuit is presented in the Fig. 1. The reaction crucible had the form of a truncated cone with a hermetic cover made of metal tungsten. 
The following electrodes were put into the crucible of the electrolyzer: two graphite anodes and a cathode that can be made of different materials (a tungsten cathode is for the production of metal neodymium; an iron cathode is for the production of Nd-Fe foundry alloy). Ready electrolyte, consisting of metal fluorides or chlorides and neodymium oxide, was charged into the crucible. The electrolyzer was placed into a resistance furnace with the operating heating temperature of $1300^{\circ} \mathrm{C}$.

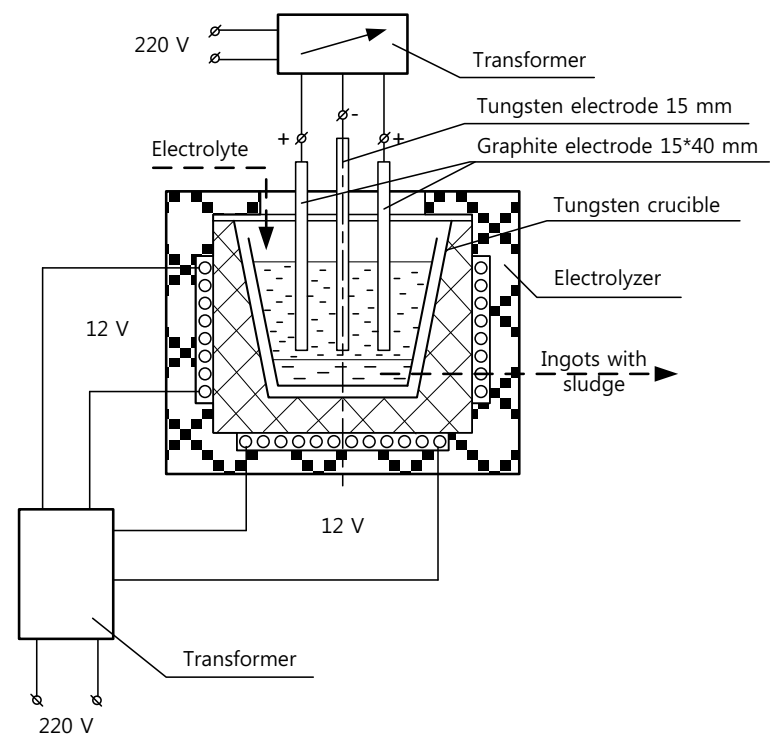

Fig. 1. Principle circuit of the electrolyzer.

The electrolyzer was assembled and charged with salts; after the preliminary vacuumization it was filled with argon; then it was heated up to the salt melting temperature and direct current flowed through the molten salts. During electrolysis the electrolyte was stirred by an agitator. To neutralize the gases, evolved during the electrolysis at the anode, they were run through the barium hydroxide solution.

The ingot of Nd-Fe foundry alloy, obtained by electrolysis, was tested for the content of neodymium, iron and other elements.

During the electrolytic production of the foundry alloy, neodymium fluoride and neodymium oxide were used as consumable compounds of neodymium. Their chemical composition is presented in the table 1 .

Table 1. Chemical composition of neodymium fluoride and neodymium oxide.

\begin{tabular}{|c|c|c|c|c|}
\hline \multirow{2}{*}{$\begin{array}{c}\text { Neodymium } \\
\text { compounds }\end{array}$} & \multicolumn{4}{|c|}{$\begin{array}{c}\text { Chemical composition of neodymium } \\
\text { fluoride and neodymium oxide, wt\% }\end{array}$} \\
\cline { 2 - 5 } & $\mathrm{Nd}$ & $\mathrm{Pr}$ & $\mathrm{Cu}$ & $\mathrm{Ni}$ \\
\hline $\mathrm{Nd}_{2} \mathrm{O}_{3}$ & 77.7 & 1.3 & 0.06 & 0.03 \\
\hline $\mathrm{NdF}_{3}$ & 69.6 & 1.2 & 0.03 & 0.3 \\
\hline & $\mathrm{Ca}$ & $\mathrm{Al}$ & $\mathrm{Mg}$ & $\mathrm{F}$ \\
\hline $\mathrm{Nd}_{2} \mathrm{O}_{3}$ & 0.009 & 0.009 & 0.3 & - \\
\hline $\mathrm{NdF}_{3}$ & 0.06 & 0.02 & 0.3 & 27.9 \\
\hline
\end{tabular}

\subsection{Production of $\mathrm{Nd}-\mathrm{Fe}$ foundry alloy by the electrolysis of neodymium fluoride}

Fluoride $\left(\mathrm{NdF}_{3}-\mathrm{LiF}-\mathrm{BaF}_{2}\right)$ and chloride-fluoride $\left(\mathrm{BaCl}_{2}-\mathrm{LiCl}-\mathrm{NdF}_{3}-\mathrm{LiF}\right)$ molten salts, containing 25$40 \mathrm{wt} \% \mathrm{NdF}_{3}$, were tested as an electrolyte for the electrolysis of neodymium fluoride. During the electrolysis of these melts at the electrodes the following reactions are taking place:

at the graphite anode:

at the iron cathode:

$$
\begin{gathered}
2 \mathrm{~F}^{-1}-2 \mathrm{e} \rightarrow \mathrm{F}_{2} \text { (gas), } \\
\mathrm{C}+2 \mathrm{~F}_{2} \rightarrow \mathrm{CF}_{4} \text { (gas), } \\
2 \mathrm{Cl}^{-1}-2 \mathrm{e} \rightarrow \mathrm{Cl}_{2} \text { (gas), }
\end{gathered}
$$

$$
\mathrm{Nd}^{+3}+3 \mathrm{e} \rightarrow \mathrm{Nd}
$$

$\mathrm{Nd}+\mathrm{Fe} \rightarrow \mathrm{Nd}_{2} \mathrm{Fe}+\alpha-\mathrm{Nd}-$ low-melting eutectic

$$
\left(\mathrm{T}_{\mathrm{m}}=640^{\circ} \mathrm{C}\right) \text {. }
$$

Figures 2 and 3 show the influence of the cathodic current density $\left(i_{K}\right)$ on the current efficiency $\left(\eta_{T}\right)$ for neodymium into the cathodic product during $\mathrm{NdF}_{3}$ electrolysis.

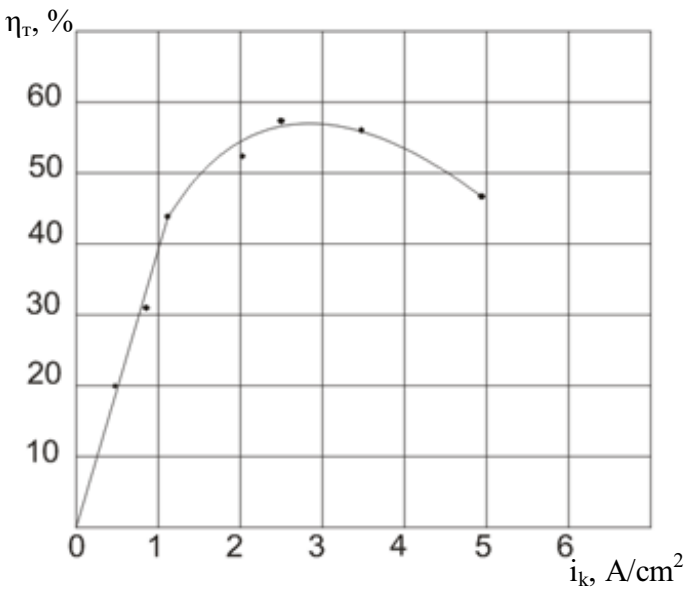

Fig. 2. Dependence of the current efficiency for neodymium on the cathodic current density at the temperature of the process $\mathrm{t}=850^{\circ} \mathrm{C}$ (electrolyte $\mathrm{NdF}_{3}-\mathrm{LiF}-\mathrm{BaF}_{2}$ ).

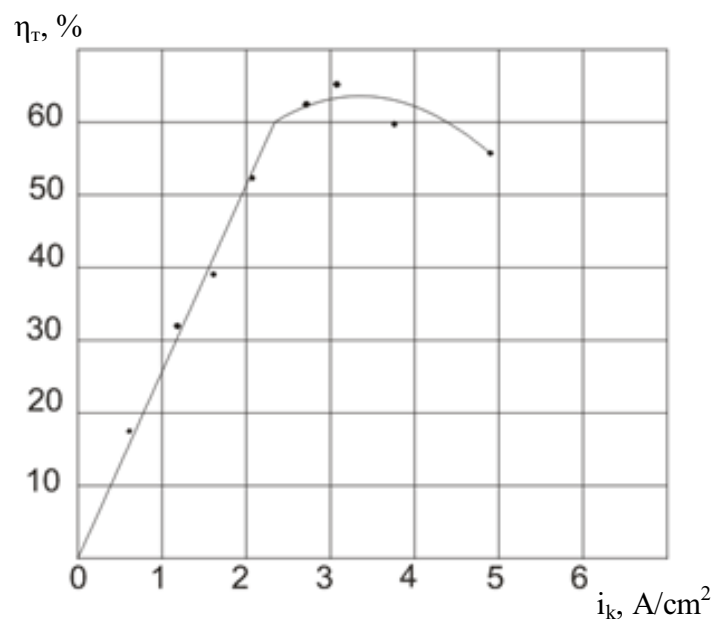

Fig. 3. Dependence of the current efficiency for neodymium on the cathodic current density at the temperature of the process $\mathrm{t}=750^{\circ} \mathrm{C}$ (electrolyte $\left.\mathrm{BaCl}_{2}-\mathrm{LiCl}-\mathrm{NdF}_{3}-\mathrm{LiF}\right)$. 
During the electrolysis of $\mathrm{NdF}_{3}$ in fluoride and chloride molten salts, the neodymium content in the cathodic product was changing from 78.2 to $80.1 \mathrm{wt} \%$. At the same time the optimal current efficiency for neodymium was $\eta_{\mathrm{T}} \approx 58-60 \%$ during electrolysis in the fluoride electrolyte and $\eta_{\mathrm{T}} \approx 62-66 \%$ - in the chloridefluoride electrolyte.

\subsection{Production of Nd-Fe foundry alloy by the electrolysis of neodymium oxide}

As an electrolyte for the electrolysis of neodymium oxide there have been tested fluoride molten salts of $\mathrm{NdF}_{3}-\mathrm{LiF}-\mathrm{BaF}_{2}$ composition, containing 40-60 wt $\%$ $\mathrm{NdF}_{3}$, in which solubility of $\mathrm{Nd}_{2} \mathrm{O}_{3}$ reached 5-7 wt \%, which is sufficient for the oxide electrolysis. During the electrolysis of neodymium oxide in fluoride melts at the electrodes the following reactions are taking place: at the graphite anode:

$$
\begin{gathered}
2 \mathrm{O}^{-2}-4 \mathrm{e} \rightarrow \mathrm{O}_{2}, \\
\mathrm{C}+\mathrm{O}_{2} \rightarrow \mathrm{CO}_{2} \text { (gas), } \\
2 \mathrm{C}+\mathrm{O}_{2} \rightarrow 2 \mathrm{CO} \text { (gas), }
\end{gathered}
$$

at the iron cathode:

$$
\mathrm{Nd}^{+3}+3 \mathrm{e} \rightarrow \mathrm{Nd}
$$

$\mathrm{Nd}+\mathrm{Fe} \rightarrow \mathrm{Nd}_{2} \mathrm{Fe}+\alpha-\mathrm{Nd}-$ low-melting eutectic.

Figure 4 shows the influence of $i_{K}$ on $\eta_{T}$ during the electrolysis of neodymium oxide in the fluoride electrolyte.

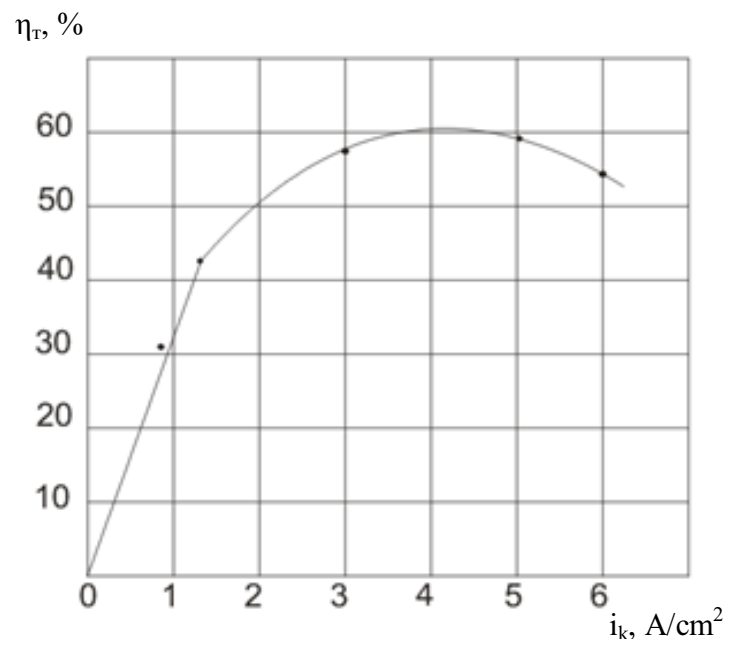

Fig. 4. Dependence of the current efficiency for neodymium on the cathodic current density at the temperature of the process $\mathrm{t}=850^{\circ} \mathrm{C}$ (electrolyte $\left.\mathrm{BaF}_{2}-\mathrm{NdF}_{3}-\mathrm{LiF}\right)$.

The electrolysis of neodymium oxide was stopped after precipitation of the sparingly soluble barium carbonate from the solution-neutralizer due to the reaction taking place between carbon dioxide, evolving at the graphite anode, and the barium hydroxide solution:

$$
\mathrm{CO}_{2}+\mathrm{Ba}(\mathrm{OH})_{2} \rightarrow \mathrm{BaCO}_{3}+\mathrm{H}_{2} \mathrm{O} \text {. }
$$

The optimal current efficiency for neodymium was $\eta_{\mathrm{T}} \approx 58-60 \%$ during $\mathrm{Nd}_{2} \mathrm{O}_{3}$ electrolysis in the fluoride electrolyte.

Figure 5 shows the history of the electrolysis of neodymium oxide in time. Voltage variation at the iron cathode during $\mathrm{NdF}_{3}$ electrolysis with periodicity of 5-7 minutes has stick-slip nature. This is due to detachment of droplets of liquid $\mathrm{Nd}-\mathrm{Fe}$ foundry alloy from the cathode to the bottom of the electrolysis cell (the tungsten crucible).

Table 2 presents the results of experiments on neodymium oxide electrolysis in the fluoride electrolyte $\mathrm{BaF}_{2}-\mathrm{NdF}_{3}-\mathrm{LiF}$ in the selected mode with neodymium oxide loading during electrolysis.

Conditions for electrolysis:

- the electrolyte composition, wt $\%: 13 \mathrm{BaF}_{2}-60 \mathrm{NdF}_{3}-$ $27 \mathrm{LiF}$,

- parameters: $\mathrm{i}_{\mathrm{A}}=0.8-1.0 \mathrm{~A} / \mathrm{cm}^{2}, \mathrm{t}=850^{\circ} \mathrm{C}, \tau=6$ hours, - portions of $\mathrm{Nd}_{2} \mathrm{O}_{3}$, weighing 15-20 g, were immersed into the electrolyte every 60 minutes.

\begin{tabular}{|c|c|c|c|c|c|}
\hline \multirow[b]{2}{*}{ No } & \multirow{2}{*}{\multicolumn{2}{|c|}{$\begin{array}{l}\text { Weight of } \\
\text { given } \\
\text { electrolyte, } g\end{array}$}} & \multicolumn{2}{|c|}{ Processed, g } & \multirow{2}{*}{$\begin{array}{l}\text { Obtained } \\
\text { Nd-Fe } \\
\text { foundry } \\
\text { alloy, g }\end{array}$} \\
\hline & & & $\mathrm{Nd}_{2} \mathrm{O}_{3}$ & $\begin{array}{c}\mathbf{N d} \\
\text { with } \\
\mathrm{Nd}_{2} \mathrm{O}_{3}\end{array}$ & \\
\hline 1 & \multicolumn{2}{|c|}{620} & 100 & 73.8 & 90.4 \\
\hline 2 & \multicolumn{2}{|c|}{600} & 150 & 110.7 & 128.3 \\
\hline 3 & \multicolumn{2}{|c|}{700} & 100 & 73.8 & 82.3 \\
\hline 4 & \multicolumn{2}{|c|}{700} & 150 & 110.7 & 130.6 \\
\hline 5 & \multicolumn{2}{|c|}{650} & 130 & 95.9 & 110.0 \\
\hline 6 & \multicolumn{2}{|c|}{600} & 100 & 73.8 & 90.8 \\
\hline \multirow[t]{2}{*}{ No } & \multicolumn{2}{|c|}{$\begin{array}{l}\text { Foundry alloy } \\
\text { composition, } \\
\text { wt } \%\end{array}$} & \multirow{2}{*}{\multicolumn{2}{|c|}{$\begin{array}{l}\text { Amount of } \mathrm{Nd} \text { in } \\
\text { Nd-Fe foundry } \\
\text { alloy, } g\end{array}$}} & \multirow{2}{*}{$\begin{array}{c}\text { Current } \\
\text { efficiency, } \\
\eta_{\mathrm{T}}, \%\end{array}$} \\
\hline & Nd & $\mathbf{F e}$ & & & \\
\hline 1 & 80.3 & 14.3 & \multicolumn{2}{|c|}{72.6} & 98.4 \\
\hline 2 & 83.3 & 13.9 & \multicolumn{2}{|c|}{107.0} & 96.7 \\
\hline 3 & 82.4 & 13.8 & \multicolumn{2}{|c|}{67.8} & 91.9 \\
\hline 4 & 83.7 & 16.8 & \multicolumn{2}{|c|}{109.3} & 98.7 \\
\hline 5 & 81.4 & 15.2 & \multicolumn{2}{|c|}{89.6} & 93.4 \\
\hline 6 & 80.3 & 16.1 & \multicolumn{2}{|c|}{72.9} & 98.8 \\
\hline
\end{tabular}

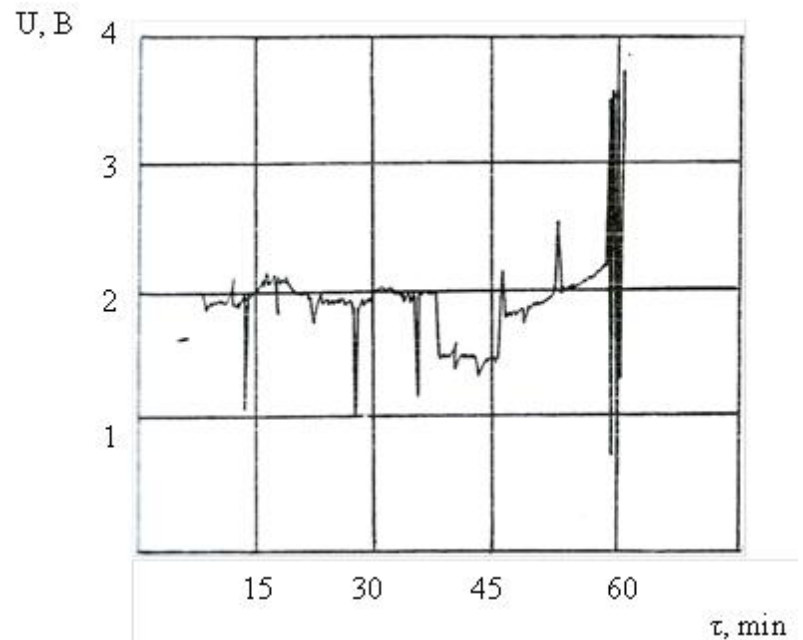

Fig. 5. Potential variation of the cathode in time.

Table 2. Results of experiments on neodymium oxide electrolysis in the fluoride electrolyte.

Table 3 presents the results of the analysis of the $\mathrm{Nd}$ Fe foundry alloy ingot, obtained by neodymium oxide electrolysis in the molten fluoride salts $\left(\mathrm{BaF}_{2}-\mathrm{NdF}_{3}-\right.$ LiF). 
Table 3. Chemical composition of the Nd-Fe foundry alloy ingot.

\begin{tabular}{|c|c|c|c|c|c|c|c|}
\hline Element & Nd & Fe & Pr & Cu & Ni & Al & C \\
\hline $\begin{array}{c}\text { Content, } \\
\mathrm{wt} \%\end{array}$ & 83.4 & 14.0 & 2.2 & 0.15 & 0.15 & 0.03 & 0.02 \\
\hline
\end{tabular}

Data presented in table 3 show that the overall content of all impurities in the foundry alloy does not exceed $0.4 \% \mathrm{wt}$.

\section{Conclusion}

The study of the electroplating technique of production of $\mathrm{Nd}-\mathrm{Fe}$ foundry alloy in fluoride, chloride-fluoride and oxide-fluoride molten salts has been carried out;

- it has been determined that during electrolysis of $\mathrm{Nd}_{2} \mathrm{O}_{3}$ and $\mathrm{NdF}_{3}$ in $\mathrm{BaF}_{2}-\mathrm{NdF}_{3}-\mathrm{LiF}$ melt and during electrolysis of $\mathrm{NdF}_{3}$ in $\mathrm{BaCl}_{2}-\mathrm{LiCl}-\mathrm{NdF}_{3}-\mathrm{LiF}$ melt, lowmelting eutectic of iron and neodymium is formed at the iron cathode. The content of the low-melting eutectic of iron and neodymium is close to the calculated composition of the foundry alloy;

- under optimum conditions of $\mathrm{Nd}_{2} \mathrm{O}_{3}$ electrolysis in a fluoride molten salt, neodymium yield into the cathode product reaches $98.4-98.8 \%$, which is significantly higher than during $\mathrm{NdF}_{3}$ electrolysis; thus, this method is very promising for production of materials containing $\mathrm{Nd}$ and, apparently, other rare-earth metals.

The work was made under the aegis of the Federal goaloriented program "Researches and design of foreground directions of development of Russia's scientific-andtechnological system in 2014-2020" (RFMEFI57814X0018).

\section{References}

1. A. Bujnovskij, V. Sachkov, V. Sofronov, A. Anufrieva, Adv. Mater. Res. J. 1085, 209 (2015)

2. F.J.G. Landgraf, G.S. Schneider, V. Villas-Boas, F.P. Missel, Less-Common Met. J. 163, 209 (1990)

3. V. Grebnev, V. Dmitrienko, Bul. of the TPU J. 311, 70 (2007)

4. V. Soare, M. Burada, T. Ostvold, C. Kontoyannis and E. Stefanidaki, Min. and Met. J. 39, 209 (2003)

5. M.F. Chambers, J.E. Murphy, BUREAU of MINES Report of Investigations, 9391 (1991)

6. S. Singh, J. M. Juneja, D. K. Bose, Appl. Electrochem. J. V 25, 1139 (1995)

7. S. Jiao, H. Zhu, Hazard. Mater. J. V 189, 821 (2011) 